\title{
BUKALAPAK AND THE REPRESENTATION OF THE CHINESE ETHNIC IN THEIR 'BU LINDA' ADVERTISEMENT
}

\author{
Bella Arista ${ }^{*}$, Abhirama Perdana ${ }^{2}$ \\ President University \\ *Bellaarista17@gmail.com
}

\begin{abstract}
Indonesia is a diverse country of tribe and culture, where differences can sometimes lead to pros and cons in the society. Media representatives should continue to describe each ethnicity in Indonesia by upholding good values, traditions, and social roles in society. Media today needs to be shifted to describe a particular ethnic/ethnic group in a more convenient way without eroding social norms, cultures, and beliefs in the society. Bukalapak's advertisement, entitled "Bu Linda", reflects the other side of a Chinese descendant in Indonesia and also reflects on the idea of inter-ethnic harmony, this study analyses Bukalapak's advertisement with the title "Bu Linda" using Critical Public Relations Analysis with Visual Grammar from the Social Semiotics Approach. The purpose of this study is to explore how Bukalapak represent the Chinese descendants in Indonesia through its advertisement.
\end{abstract}

Keywords: Chinese ethnicity, critical public relations, representation

\section{INTRODUCTION}

Chinese descendant in Indonesia is one of the minority ethnics that Indonesia had, they portrayed as group of people who takes every advantage to their own good. That statement is supported by the research that published by Forbes magazine in 2016 that released the list of the richest people in Indonesia. The fact is $90 \%$ of people in that list are from Chinese descendant in Indonesia. This result is very interesting which in fact the population of Chines ethnic just around 3\% in Indonesia. Of course, by this fact created social jealousy between the social ethnic in our country.

Because of the social jealousy in society, then it starts to create another impact which is racism. According to Australian Human Rights Commission (2014), "Racism is more than just words or actions, it also includes the invisible barriers, big and small, that can prevent people from doing as well in life as others simply because of their cultural background". All through history, mankind has treated others with scorn and unethical behaviour upon them due to the shade of their skin or the way of life from which they come. Racism and savagery against individuals of Chinese descendant in Indonesia has been recorded since no less than 1740, when the Dutch Colonial Government slaughtered up to 10,000 individuals of Chinese descendant during the Chinezenmoord. In the period from that point forward, separation and savagery have been recorded with respect to both remote and Indonesian governments. The most exceedingly terrible episodes occurred in 1965 after the failed coup attempt during anticommunist purges and in 1998, when Chinese businesses were coercively burned to the ground and devastated, while many ladies assaulted amid the May riots. The segregation can appear as savagery, phrasing or dialect utilize, and prohibitive enactment. Because of this segregation, Chinese Indonesians have endured a character emergency, unfit to be acknowledged by both local Chinese and local Indonesians.

The advertisement of Bukalapak with title: "Bu Linda" is an example of ethnic equality in Indonesia. Bukalapak is one of the biggest online marketplaces in Indonesia, in here they provided a buying and selling services from consumers to consumers. Anyone can open the online store in Bukalapak and serve buyers from all over Indonesia for single or various unit transactions. Bukalapak additionally portrays the significance of a general family through the advertisement of 'Bu Linda'. This advertisement truly touches and shows that the distinction is not an obstacle for us to live in harmony. 
Actually, the bond of the heart is deeper than the bond of blood. This is exceptionally fitting with the moment of the Indonesian who recently was buffeted by the issue of disunity and enmity because of the element of difference. Advertisement in Bukalapak.com is telling a story about the owner of boarding house, she is descendants of China in Indonesia named Bu Linda who very fussy but behind it all $\mathrm{Bu}$ Linda is a good figure and very understanding. As the owner of the boarding house, she also became a mother figure for his 2 boarding children named Ari which is from Java ethnic and Mario which is an Ambon ethnic. The video of this advertisement is published to YouTube on January 26, 2017. It already watches by $2,144,958$ viewers and got 36.000 likes and 1.200 dislikes.

The perspectives of how the people see something, in this context arethat ethnic is influenced by media, since media has turned out to be so unavoidable and been capable in conveying its message towards society todays. The ways media depicted Chinese ethnic in Indonesia delude how we see this ethnic group. With respect to view of this reality, Bukalapak enhanced a thought to rethink an expression of awful Chinese ethnic through publicizing to change presence designs among society from an affront into an equality towards diversity. Consequently, researchers might want to examine on how this advertising can convey its message through textual and visual analysis. Supporting the achievement of this advertisement in our nation, the thought is worth to be actualized in Indonesia, since now Indonesia faces some of obstacles in keeping the Bhineka Tunggal Ika.

\section{THEORETICAL FRAMEWORK}

Indonesia is an archipelago country who has 300 ethnic groups in it. One of the ethnic inside it is Chinese ethnic. This ethnic group comes to Indonesia because of the rise and falls of various dynasties at that time in China, that it causes a massive migration of Chinese people. Another reason is because of the nature of Chinese people itself that like to explore new places. An expedition that led by Cheng Ho in early $15^{\text {th }}$ century is one of the biggest expeditions at that time, construct a Chinese-Muslim colony in Palembang, those were refugees and farmers just like many of natives in Indonesia at that time.

At first the relationship between all the ethnic is fine until the Dutch colonial era, because since Chinese very capable in business, they become intermediary between both invaders and native people. This phenomenon brings Chinese ethnic at that time have a higher hierarchy than the natives, so it becomes on the top is Dutch, then Chinese, and the last is natives. After independence of Indonesia, the Japanese and Dutch were basically just abandoned their company in Indonesia. That is makes the new government at that time sold the company with a low price. Of course, the Chinese-Indonesians took this change quickly and took over these companies. However, numerous natives do not like this effort, they started blaming that Chinese-Indonesians was being unpatriotic during the war (since they rarely engaged in equipped war). The young Indonesian government has forced many people to hand over their goods. This will be the first of many limitations on China-Indonesia individual rights.

Until 1950s and 1960s during the reign of President Soekarno (the $1^{\text {st }}$ Indonesian President), the stereotype that Chinese people think is very economical is still there. This cannot be denied because during the colonization, dunch have a regulation to keep the natives to work at the farm and let the Chinese run their business. Therefore, once Indonesia become independent, almost every retail store in Indonesia was owned by ethnic Chinese. Then In 1959, President Soekarno affirmed a mandate that constrained Chinese-Indonesians to close their business in country ranges and migrate to urban regions. Implementation was severe and numerous entrepreneurs were slaughtered.Separation deteriorated as the economy was additionally overwhelmed by Chinese-Indonesians. The natives grumbled of the administration's dull endeavours in making a "level playing field" (there were requests for extraordinary natives' benefits that would permit less immediate rivalry with the Chinese-Indonesian organizations) making considerably more pressure. This further raised the officially uneasy relationship, as natives had since quite a while ago thought to be Chinese-Indonesians to be in conspire with the colonial administration. The inclination of Chinese-Indonesians to stick together in Chinatowns, isolating themselves from the natives, just exacerbated the circumstance.

However, during that period of Suharto (the $2^{\text {nd }}$ Indonesia President) the Chinese people were given back the opportunity to encourage economic growth in the country. He needed economic growth as a result of the political struggle that the country passed after a failed 1965 coup. so, the next two decades are known as the moment of great economic prosperity in Indonesia with the Chinese- 
Indonesian leading by expanding their business. In a 1995 study published by the East Asian Institute of Analytical Affairs of the Department of Foreign Affairs and Trade, about 73 percent of the market capitalization value of public companies (excluding foreign companies and state-owned enterprises) was owned by the Chinese-Indonesians.

\section{Media Representation}

From the social world, media describes and makes ideas of social representations. For example, the mass media describes a series of characterizations that associate different groups of identities with different possibilities for being someone for example, like how someone behaves in society (Leavitt, P.A., Covarrubias, R. and Perez, Y.A., 2015).

As multi-cultural country of course, Indonesia having trouble in the way media represented each ethnic. One of the difficulties for multi-social society is the means by which the effective interaction between the society, the only way each society can learn and knowing each other is by representation of the media. Therefore, the media have an intense part to play, and need to guarantee that they consistently strengthen generalizations in media (Kidd, 2016). One of the form of media bias is personalization bias. This can be once a media outlet focuses on a private human tragedy or the negative parts of a story rather than observing the larger image in terms of social group, economic or political impacts (Forman, 2015, Nainggolan, 2017).For people who don't have a power and clear understanding regarding who they have to trust, media representation sure bringing the media to reality for them, by offering messages about various groups and about how to understand or think about the social world they are living (Leavitt, P.A., Covarrubias, R. and Perez, Y.A., 2015).Surely by the fact the responsibility of a media is really high not just about spreading information but also for the unity of the country.

\section{Critical Discourse Analysis}

According to Fairclough, N (2012), Critical discourse analysis (CDA) is a branch of critical social analysis, which contributes to the latter a focus on discourse and on relations between discourse and other social elements (e.g. on how discourse figures in ideologies and power relations). CDA brings the crucial tradition in social analysis into language-studies, and contributes to crucial social analysis a specific target discourse and alternative social components (power relations, ideologist, institutions, social identities, and others).

The term CDA is employed these days to refer a lot of specifically to the crucial linguistic approach of students United Nations agency and also the larger discursive unit of text to be the fundamental unit of communication. This analysis specifically considers institutional, political, gender and media discourses (in the broadest sense) that testify to a lot of or less barefaced relations of struggle and conflict. The variations between CDA and alternative linguistics approaches could also be most clearly established with relevance the final principles of CDA. Initial of all character of the issues with that $\mathrm{CDA}$ is bothered is totally different in essence from all those strategies that don't confirm their interest ahead. Generally, CDA asks totally different analysis queries. CDA students play associated degree advocatory role for teams that suffer from social discrimination. If we glance at the CDA contributions collected during this reader it becomes evident that the road drawn between social scientific analysis that has got to be intelligible, and political argumentation is usually crossed. Regardless of the case, in respect of the item of investigation, it's an indisputable fact that CDA follows a distinct and a crucial approach to issues, since it endeavours to form specific power relationships that area unit often hidden, and thereby to derive result that area unit of sensible connection. (Meyer \&Wodak, 2009).

Critical discourse analysis (CDA) is accepted to have mindfulness in the relations amongst language and power. This investigation serves to centers the examination around the significance making in texts and its change in social life. Critical discourse analysis by Fairclough is divided into three dimensions: (1) textual form of analysis - spoken, written, or visual; (2) the interpretation of meanings; and (3) discourse in social practice. The first dimension represents fracture of a "text" which include but not limited to object of analysis, verbal, visual verbal, and visual text. The first dimension speaks about the object that going to be analysed (like visual, verbal or texts on verbal and visual); the second dimension can be portrayed as the legal action in produced and received (composition/talking/outlining and perusing/viewing, and etc.) by the people in society. lastly, the third dimension could be portrayed as 'control behind discourse' or as social practices, since it is containing 
"the socio-chronicled conditions that oversee these procedures. For each dimension, there must be led an alternate sort of investigation: for the first dimension 'content analysis or portrayal', for the second dimension 'preparing analysis or elucidation', and for the third dimension it is the 'social analysis or clarification'. All dimensions are associated and, in this manner, it doesn't make a difference with which sort of investigation one starts; they are "commonly informative". In their interconnections "the investigator finds fascinating examples and disjunctions that should be depicted, deciphered and clarified" (Christania, 2017).

\section{Social semiotic and visual grammar}

Visual grammar uses otherwise called Visual Semiotic Analysis of visual communication created by Jewitt and Oyama as an approach to outwardly feel the relations between picture to have a more particular sort of semiotic. It clarifies what a picture can convey message and scattered by the audiences and also how individuals and picture can coordinate their esteem and have same understanding.

Harrison believed on three classifications of pictures: the icon, index, and symbol. Icon goes about as a suggestion to the individual or question that is common. Icon may incorporate artistic creations, maps, models, and so forth. Index is something that we know through the comparable story, esteem, and meaning which is being shared and translated from something. Index ascend as an idea of some story to practical likeness. Symbol is something that does not have a concept or form, but rather individuals can comprehend the importance of the image for the learning processes. Along these lines, that the image can be comprehended by the society around.

The procedure of conceptual picture is classificatory, which represent to the RP (represented participant) as a specific group in a similar class. Systematic process, RPs turn into a piece of "partwhole" structure which identify with each other, for instance, pie chart, diagrams, etc. In conclusion, symbolic process shows RPs to take after certain and particular importance to impart to the watchers.

\section{Interpersonal metafunction}

Interpersonal metafunction examine more about the activity or the conduct of the members associated with a picture. That conduct can be identified with the relationship among members with the vector and members with the watchers. In view of the hypothesis from van Leeuwen, the procedure of relational metafunction is identified with the picture Act and Gaze or, social separation and closeness (which appeared by the members in the photo and in addition point of view of camera angle) that will decide the relationship of the position between the watcher and the members in the photo. This procedure additionally can decide the objective in the relational relationship that can be found in the photo. According to Van Leeuwen, Interpersonal metafunction is partitioned into 3 classes that can further dissect the picture. 1) contact which that break down in view of the look or the eye to eye connection of the members whether coordinate eye to eye connection (Demand) or non-coordinate eye to eye connection (Offer). 2) social distance that will decide through the camera shot of the photo whether extraordinary close up shot which all the more indicating head-shoulder (intimate relationship), medium shot which all the more appearing down to abdomen of member's body (social relationship), and long-extraordinary long shot which all the more appearing to all the body of members until nature around (impersonal relationship). 3) attitude, which more examine utilizing camera angle that partitioned into subjective (the picture that can be seen subjectively) and objectivity (graph/outline).

\section{Compositional metafunction}

The compositional metafunction is the connection between the illustrative and relational metafunction to incorporate the importance meaning. The components of the compositional metafunction are value, salience, framing, and modality. Data estimation of compositional metafunction is breaking down the place of member in the picture, regardless of whether at the inside (focused) or in favor of a picture (Polarized). In view of Harrison, data esteem is partitioned into 2 classifications. The principal class is centered and the second class is polarized. The second class in compositional metafunction is notability decided from the profundity of the color, gradation, and size of the picture. The third classification is surrounding which decides the association between the member and the vector or the member and other member/watchers whether it is inside or remotely.

\section{Representational Metafuntion}


Kress and Leeuwen have isolated the illustrative metafunction into two structures, which are narrative and conceptual structure. While narrative structure is more represents to the procedure and the arrangement of the participants in the general public, the conceptual structure more represents to the participants on investigating meaning. For narrative structure, Kress and Leeuwen abridge that there are 2 sections of the operator in a procedure, the actors and the vector, where the on-screen actors is every member that effectively joins the procedure and the vector that support the goals. The procedures of represent metafunction are in view of the agentive (the activity that members do and acknowledge by the members itself) or non-agentive. Agentive process is separated into 2 sections of picture which is projective (the activity is portrayed by the content in an air bubble/cartoon), or non-projective. For non-projective it is partitioned into two procedures which can be seen by the look of the members, which are activity process and response process. For activity, there are two forms that can examine the importance which are controlled by the objective of the picture. To start with is transactional (the activity demonstrating that there is a goal in it) and non- transactional (which is not demonstrating any goal in the picture). transactional process is partitioned into two unidirectional and bidirectional. Unidirectional is the help members that are not individual and bidirectional is the supporting members in the picture that are individual.

\section{METHOD}

The researchers decided to analyze the advertisement from Bukalapak. Primary data from this research is Bukalapak video advertisement: 'Bu Linda' from application Youtube in January, 2017. Other supporting data that serve as secondary data such as literature, journals, books, and so on. This study examines to answer the following research questions: (1) How Bukalapak represent Bu Linda as Chinese ethnic in their advertisement?, (2) How the video advertisement redefines the meaning of unity in diversity?

This paper was investigated by utilizing Critical Discourse Analysis combine with social semiotic analysis and visual grammar. Critical Discourse Analysis (CDA) is a linguistic study particularly as social practices. Critical Discourse Analysis is accepted as a standout amongst the best way in doing social research because of its connection in making language as a crucial part in social life. In analyzing 'Bu Linda' advertisement campaign, researchers use Fairclough model. Critical Discourse Analysis proposed by Fairclough is utilized to look at the detail of this analysis. CDA by Fairclough separated by three dimensions: (1) textual form of analysis - talking, writing, or visual; (2) the interpretation of meanings; and (3) discourse in social practice. By using visual grammar of metafunction to examined the first-dimension, three metafunction are: (1) representational metafunction, (2) interactional metafunction, (3) compositional metafunction. The second-measurement broke down by utilizing intersemiotic relations as content as the primary properties and took after by the picture to help verbal content. Intersemiotic investigation alludes to draw in the relations amongst content and picture inside one idea of news story (Caple, 2013). The third-measurement clarified by utilizing cross-finding examination from first and second measurement which fabricate the power connection shared inside the commercial.

\section{RESULT AND DISCUSSION}

The way Bukalapak represent Chinese ethnic in the advertisement with title 'Bu Linda'
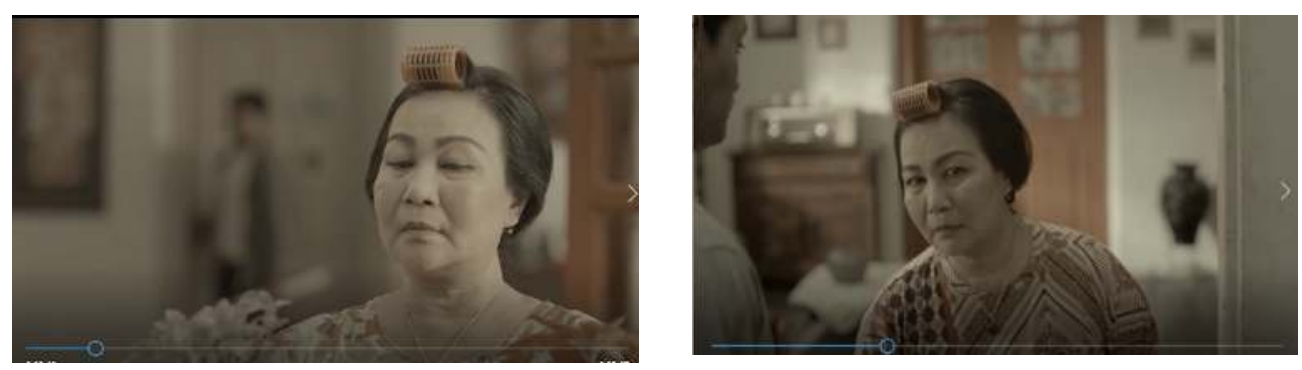
Figure 1

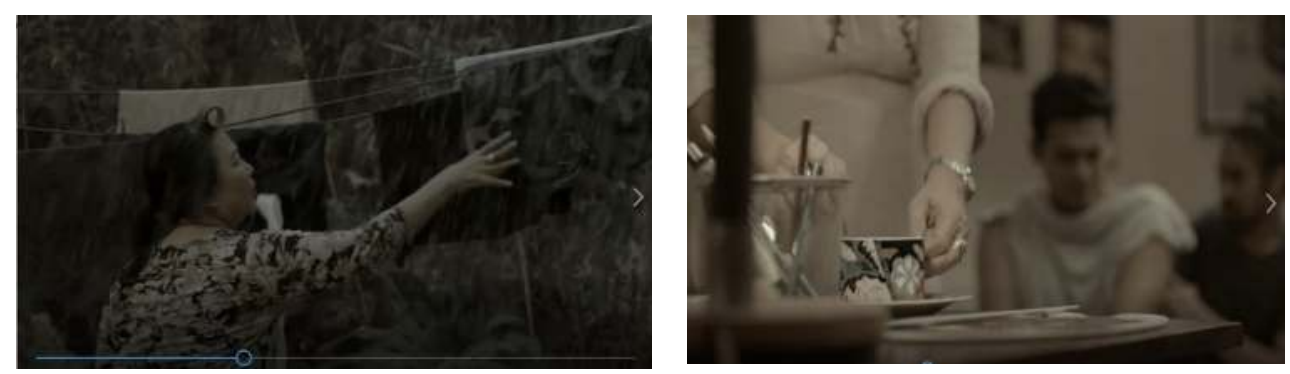

Figure 2

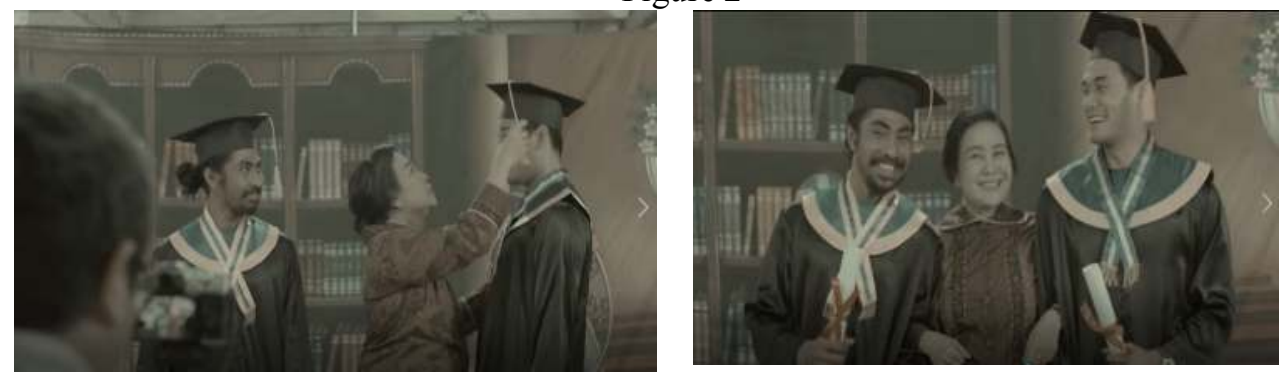

Figure 3
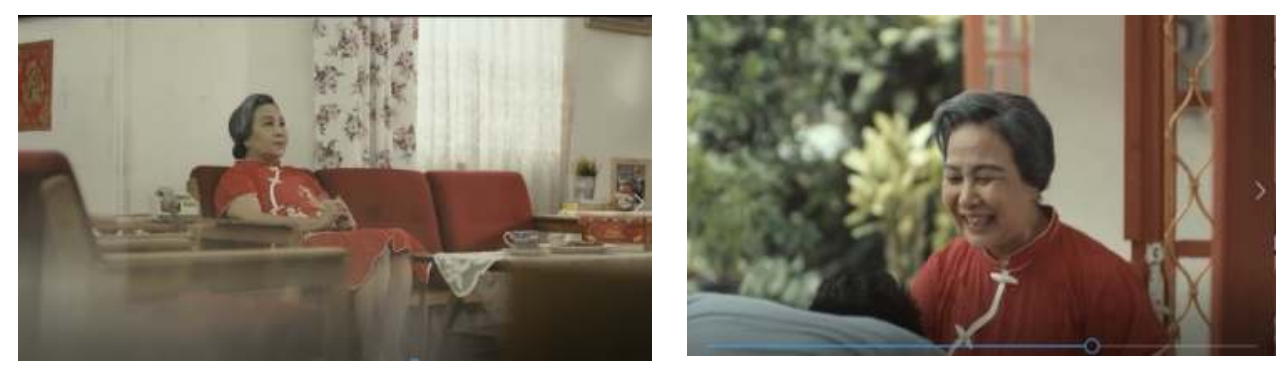
Figure 4

\begin{tabular}{|c|c|c|c|c|}
\hline 4.5 & Picture & $\begin{array}{l}\text { Still showing goal in } \\
\text { it, because in this picture she } \\
\text { is trying to make sure that } \\
\text { her child is looking well for } \\
\text { the graduation picture.means } \\
\text { that she is very detail in } \\
\text { taking care of her children. }\end{array}$ & Same as picture & $\begin{array}{l}\quad \text { The actor } \\
\text { positions is on the centre } \\
\text { of both of her sons } \\
\text { showing maximum } \\
\text { connection between the } \\
\text { RPs. }\end{array}$ \\
\hline 4.6 & Picture & $\begin{array}{l}\text { This picture is telling } \\
\text { the actor reaction to the } \\
\text { photographer, because they } \\
\text { are taking graduation picture } \\
\text { together. by putting a big } \\
\text { smile and embracing her } 2 \\
\text { sons, showing that she is } \\
\text { happy and proud of them. }\end{array}$ & $\begin{array}{l}\text { There are eye } \\
\text { contact and a big smile } \\
\text { showing that they are } \\
\text { having happy moment } \\
\text { together. the social } \\
\text { distance is social } \\
\text { relationship and still } \\
\text { showing equality. }\end{array}$ & Same with picture \\
\hline 4.7 & Picture & \begin{tabular}{l}
\multicolumn{1}{c}{ This picture makes } \\
the viewer take a look about \\
her reaction while waiting \\
for her sons in Imlek. \\
Showing that she is very \\
patient by waiting alone \\
calmly. She also wearing \\
Chinese traditional cloth to \\
celebrating Chinese New \\
Year(imlek).
\end{tabular} & $\begin{array}{l}\text { The picture not } \\
\text { have any eye contact. The } \\
\text { social distance is } \\
\text { interpersonal, by showing } \\
\text { the room situation while } \\
\text { she waits for her children. } \\
\text { And still showing } \\
\text { equality. }\end{array}$ & $\begin{array}{l}\text { The actor is on the } \\
\text { centre of the picture and } \\
\text { showing maximum } \\
\text { salience }\end{array}$ \\
\hline 4.8 & Picture & $\begin{array}{l}\text { Showing her reaction } \\
\text { after one of her sons come to } \\
\text { visit her in imlek, in here we can } \\
\text { see that her son is kissing her } \\
\text { hand, which showing respect to } \\
\text { the elder in Indonesia culture, } \\
\text { and she accept it with a big } \\
\text { smile. }\end{array}$ & $\begin{array}{l}\text { The picture not } \\
\text { showing eye contact and the } \\
\text { social distance is intimate, } \\
\text { and also created equality } \\
\text { from the eye level angel. }\end{array}$ & Same with picture \\
\hline
\end{tabular}

From long time ago, Chinese ethnic in Indonesia have an image of wealthy people and self-caring. This picture still showing those stereotypes of Chinese ethnic but add other side of it that they are still part of Indonesia and showing equality. In here we can see that Bu Linda always looked simple with her cloth day by day, and sometimes using batik in her daily life. Even thought, she also showed as someone wealthy by the accessories that she wore, she still wants to lifting the cloth line while raining and very taking care of her children, which is have a different ethnic with her. Most of the shoot also using eye level angel who showing the equality between the RPs and the viewers, this advertisement want to convince that whatever our ethnic we are equal. There also scene that prove about diversity in unity in picture 4.8 where It shows that 2 different culture in one frame. This shows that $\mathrm{Bu}$ Linda whoia from Chinese ethnic in this advertisement hasan image of caring/not self-caring, sincere, loveable, and low-profile.

\section{Bukalapak advertisement redefines the meaning of unity in diversity}

Analysed by Using Intersemiotic Text-Image Relations.In the opening of the video, it shows the house of Bu linda, and there are some words appeared while shooting the house.

'Bu Linda'

"Terinspirasi dariKisah Nyata" ("Inspired by true story)

The words 'Bu Linda' here as the title of the video, even though bu Linda from Chinese ethnic the calls that being used to show respect for older woman is 'IBU' which is from Indonesian culture. It shows that even though $\mathrm{Bu}$ Linda is Chinese ethnic she is also part of Indonesia. The words 'terinspirasi' 
is represent that this the video maker already knows the story and feel inspired to make the video, and the word 'darikisahnyata' here showing that the story in this video is from the real reality and already happened. So, this sentence mean that this video is made from the reality that already happened.

Bu linda: "sare wae, jam seberahaie? Disiplin atuh!"/" tidurterus, jam berapaini? Disiplin dong!" (always sleeping, what time is it? Be discipline!)

Bu linda: "ingat semesteran, bobogohanwae!" / "ingat semesteran, jangan pacarana terus!" (remember your studies, do not flirting)

Here are some of Bu linda's dialog, where she talked in Sundanese. Which is represent that even though bulinda is from different ethnic than Sundanese, doesn't mean that bulinda cannot be part of it, she still can communicate well and used that language well.

Narrator: "Atau saat istimewa yang selalu kami tunggu... Imlek!" (or special moment that we always waiting for... Chinese New Year!)

The sentences that the narrator said represent that both of Bu linda's sons which is from java and ambon ethnic also celebrating Chinese New Year together with Bu linda, they also feel that moment is worth to be wait and be their favorite celebration in every year. It brings a message to the viewers that Chinese New Year/Imlek is not just a special celebration for Chinese ethnic in Indonesia, but everyone can also celebrate it together whatever the ethnic and different culture that they have.

Ari: assalamu'alaikum

Bu linda: wa'alaikumsalam

These is the dialog when Ari and his family comes to bulinda house to celebrate Chinese New Year together, we can see that Ari using greetings 'assalamu'alaikum' which is a greeting from Arabic, and is usually used by Muslim. Bu linda spontaneously reply the greeting by saying 'wa'alaikumsalam'. This is represented tolerant not just between the culture and ethnicity but also between religion. Because even though bulinda is not a Muslim like Ari and family but she still replies the greeting.

Narrator: "iya, inilah kami anak-anak $\mathrm{Bu}$ Linda. Aku Ari Jawadan Mario Ambon.KeluargatakharusKarenapertaliandarahtapijugapertalianhati." (Yeah, here we are Bu Linda's children. I'm Ari from java ethnic and Mario from Ambon ethnic. Families do not have to because of blood ties but also because of the linked of the heart).

The narrator dialog here, as the conclusion of the story in the video. It shows that even though each of them is having different culture, ethnic, and religion it's not their obstacle to live together as a family this is reflected through the dialog that said "inilah kami anak-anak Bu Linda. Aku Ari Jawadan Mario Ambon" (here we are Bu Linda's children. I'm Ari from Java ethnic and Mario from Ambon ethnic). This video also showing the beauty of unity in diversity within the scope as a family, reflected from the dialog that said "Keluarga tak harus Karena pertalian darah tapi juga pertalian hati" (families do not have to be because of blood ties but also because of the linked of the heart). It wants to create a message that families are not only about same culture, religion, blood ties and so on, but it has to be from the heart. If the relationship with heart already been established then no one can bring it down although so many differences that they have.

\section{CONCLUSION}

This video of advertisement from Bukalapak is not just an ordinary advertisement but they bring up social phenomenon that is near around the society, and tried to give positive message in it. The misunderstanding and stereotype of Chinese ethnic in Indonesia are bad, self-caring, and other negative thought already in society's mindset from long time ago. This video showing an old woman named $\mathrm{Bu}$ Linda who is very fussy but very kind as the same time, she always there to support and give attention sincerely to both of man who rented room at Bu Linda's house, she also already assumed them as her children, her family, as well as both of the man. It brings moral value to the viewer that Chinese ethnic is also part of Indonesia, and each ethnic in Indonesia can live happily with high tolerance in each other.

By this paper the researchers hope that it can change the bad image of Chinese ethnic in the society, and emerging the idea of unity in diversity value back in Indonesia, remembering there are so many conflicts regarding so many hates in Indonesia right now. 


\section{REFERENCES}

About Us.(n.d.).Retrieved from https://www.bukalapak.com/about, on August 19, 2018 at 13.03 WIB.

Christania, Jella. (2017). "Is it Good to Be Bad? Celebrity Representation Analysis of Karin Novilda (Awkarin) and Samuel Alexander (Young Lex)'s Video Clip". Thesis.President University North Cikarang.

Collective, L. $\quad$ E. $\quad$ (n.d.).Chinese-Indonesians.Retrieved from https://livinginindonesia.info/item/chinese-Indonesians/, on August 18, 2018 at 19.18 WIB.

Fairclough, N. (2009). A dialectical-relational approach to critical discourse analysis in social research, in Meyer \&Wodak.

Fairclough, N. (n.d.). Critical discourse analysis (2012). Retrieved August 19, 2018, from http://www.academia.edu/3791325/Critical_discourse_analysis_2012

Forman, D. J. (2015, June 15). Media Representation of Marijuana Legislation. Retrieved August 19, 2018, from https://www.ramapo.edu/law-jurnal/thesis/media-representation-marijuanalegislation/

Indonesia's 50 Richest 2017.(n.d.).Retrieved from https://www.forbes.com/Indonesiabillionaires/\#23770fdd45b7, on August 18, 2018 at 19.15 WIB.

Kidd, M. A. (2016). Archetypes, Stereotypes and Media Representation in a Multi-cultural Society.Procedia - Social and Behavioral Sciences, 236, 25-28. Doi: 10.1016/j.sbspro.2016.12.007

Leavitt, P.A., Covarrubias, R. and Perez, Y.A. (2015)."Frozen in time": the impact of Native American media representations on identity and self-understanding.Journal of Social Issues, 71(1), 40-43.

Najafian, Maryam. Dabaghi, Azzizollah. Hidden Language of advertising: a semiotic approach.Proceedings of the InternationalConference: DoingResearch in AppliedLinguistic.

Nainggolan, Bestian. 2017. Market Typology, Concentration, and Competition of National Media Conglomerate in Indonesia.JurnalKomunikasiIkatanSarjanaKomunikasi Indonesia. Vol 2(1): pp 27-32. http://www.jurnal-iski.or.id/index.php/jkiski/article/view/89/pdf

Santosa, Riyadi. Critical Discourse Analysis: Systematic functional linguistic. International seminar prasasti $^{\text {th }}$

What is Racism? Retrieved from https://www.humanrights.gov.au/what-racism-1, on August 18, 2018 at $19.00 \mathrm{WIB}$. 